\title{
改良トレンチ法による茶樹細根の分布パターンの観察
}

\author{
熊本県農業研究センター茶業研究所* \\ 小野亮太郎 \\ 農林水産省野菜・茶業試験場** \\ 渡辺利通 \\ (平成 6 年 3 月 30 日受理)
}

\section{Distribution Pattern of Tea Fibrous Roots in the Soil Observed by Modified Trench Method}

\author{
Ryoutaro ONO \\ Tea Research Institute, Kumamoto Prefectural Agricultural Research Center \\ Toshimichi WATANABE \\ National Research Institute of Vegetables, Ornamental Plants and Tea
}

\begin{abstract}
Modified trench method was applied for the observation of fibrous roots in tea bush. The procedure of the method was as follows:

1. Dig a trench at one side of the tea bush.

2 . Wash away $5-6 \mathrm{~cm}$ depth of surface soil on the trench wall with a power sprayer.

3 . Separate the wall surface into meshes $(5 \mathrm{~cm} \times 5 \mathrm{~cm})$ with strings.

4. Count the number of fibrous root appeared in each mesh.

5. Plot the number of root as dots on a paper which is divided into each mesh.
\end{abstract}

Fibrous roots were distributed in all directions and obliquely downward into the soil from the base of a stem.

By the modified trench method, distribution pattern of fibrous roots in the soil could be obserbed with less efforts than the traditional trench method.

\section{1 緒言}

植物の根は，地中にその分布を拡げて根群 を形成し，植物体を固定・支持するとともに， 養分や水分の吸収器官として重要な役割を 担っている。地下部の状態や根の発育状況等 は, 茶樹の物質生産機能や生育及び品質の向 上に大きく関わるものと思われる。それにも かかわらず根圈環境に関する研究は, 地上部 の調查報告に比べて極端に少ない。これは固 場での根系分布の調査に多大の労力と時間を
要することに起因するものと思われる。 茶園における根系分布の調查法としては, トレンチ法 ${ }^{3)}$, ブロック法 ${ }^{4,5,6)}$, 改良モノリス 法"), 掘り取り法5,7)などの手法が用いられて いる。チャの根系は土裹中に広く樑く分布し ているため，一年生作物に比べて広い範囲を 調査する必要がある。いずれの調查方法を用 いるにしても, 根を含む土壌を掘り出し, 根 と土を分離するために多大の労力を要する。 そのため多数の材料を扱うことが困難であ り, 根系調查は比較的少ない標本数とならざ

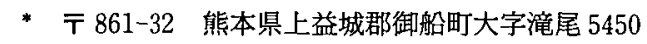

** $\bar{T} 428$ 静岡県榛原郡金谷町金谷 2769 
るを得ない。チャは永年性の畑作物であり, 株間変動が非常に大きい。また根系制御とい う観点からは各種の試験処理の組み合わせが 必要であり, 試験区の数がどうしても多くな る。従って比較的少ない労力で簡便に根系調 查が可能となるように調查法を改良する必要 がある。

围場において深耕や断根等の根系制御を行 う場合, 制御を行った地下部の細根分布状況 の変化を観察することが最も重要となる。本 報告では細根のみに注目し, その分布を比較 的容易に調査できるように従来のトレンチ法 に改良を加えるとともに, 調查結果の表現方 法についても工夫した。この改良トレンチ法 を用いることにより, 従来法に比べ比較的簡 単に細根分布の様相を把握することができた ので, その改良点と実際の茶園における細根 分布調査に適用した結果について報告する。

\section{2 材料及び方法}

本試験は 1992 年 10 月から 11 月にかけて, 農林水産省野菜・茶業試験場（金谷）内の'や ぶきた’成木園において行った。調査茶園の栽 植様式は, うね幅 $180 \mathrm{~cm}$, 株間 $30 \mathrm{~cm}$ の一条 植えである。調查は片側のうね間が $170 \mathrm{~cm}$ 空いた場所を用いて行った。

従来のトレンチ法同様に圃場にトレンチを 掘り, 土壌断面を平らにした後, 動力噴霧機 を用いて表面数 $\mathrm{cm}$ の土を水で洗い流した。 土壌断面に緹横 $5 \mathrm{~cm}$ 間隔で糸を張り, 各ま す目毎に露出している細根の数のみを計数し た。この場合, 分枝しているものはそれぞれ 1 本と計数した。

今回の調查では, うねに平行方向(うね間) 及び, 直角方向に䃯層までの深さ (約 $50 \mathrm{~cm}$ ) のトレンチを掘り, 細根の分布調査を行った。 調査時の土壌断面の様子を写真 1 に示した。

うね間は, うねと平行に株元より $60 \mathrm{~cm}$ (10 月 12 日), $40 \mathrm{~cm}$ (10月 21 日), $25 \mathrm{~cm}$ (10月 27 日) の位置で, 長さ $2 \mathrm{~m}$, 深さ $50 \mathrm{~cm}$ の断 面について調查した。うねと直角方向は, 株 元および株間中央で株位置よりうね間方向に 長さ $1 \mathrm{~m}$, 深さ $50 \mathrm{~cm}$ の断面について調査し

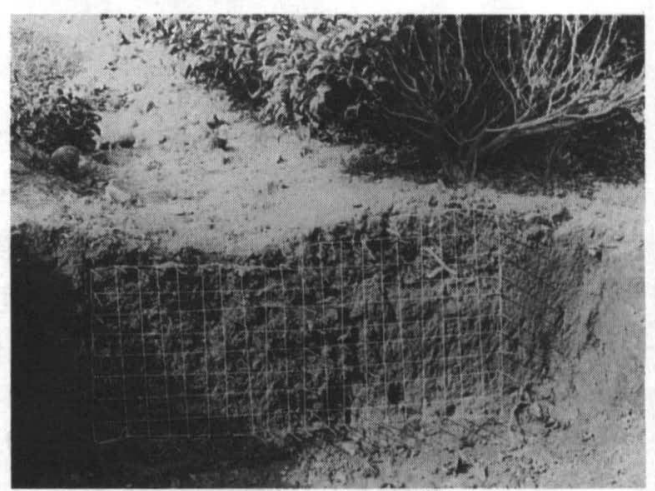

写真 1 うねに直角な方向の断面の調査状況

た（11月 16 日）。

\section{3 結果と考察}

今回の方法では, トレンチを掘るためには 従来のトレンチ法と同じ労力を必要とした が, $5 \mathrm{~cm}$ 毎の糸張り及び細根の洗い出しに はさほどの労力を必要としなかった。細根の 計数はトレンチの中で行うためやや労力と時 間を必要とし, $5 \mathrm{~cm} \times 5 \mathrm{~cm}$ のます目 100 個を計数するのに約 30 分要した。

細根の分布パターンを視覚的に把握し易く するため, 各ます目毎に計数した細根数をも とに図 1 , 図 2 を作成した。すなわち細根 1 本を 1 つの点に置き換え, 各ます目毎に細根 の数だけランダムに配置した。

うね間における細根数は, 株元から $60 \mathrm{~cm}$ 離れた断面が一番多く $\left(5,006\right.$ 本 $\left./ \mathrm{m}^{2}\right)$, 次い で $25 \mathrm{~cm}$ 離れた断面 $\left(4,299\right.$ 本 $\left./ \mathrm{m}^{2}\right)$ であり, $40 \mathrm{~cm}$ 離れた断面は一番少なかった $(1,798$ 本 $\left./ \mathrm{m}^{2}\right)$ 。細根の分布は, 株元より $25 \mathrm{~cm}$ の断 面では地表近くに多く, 地表より $10 \mathrm{~cm}$ まで でほぼ半分を占めていたが, $40 \mathrm{~cm}$ の断面で は地表近くの細根が大きく減少していた。60 $\mathrm{cm}$ の断面になると, 細根は深さ $50 \mathrm{~cm}$ まで は全面に分布していた。(図 1)

うねに直角方向の断面における細根の分布 についてみると(図 2), 株元の断面の場合に は, 株位置直下では $20 \mathrm{~cm}$ より深いところで は細根がほとんど見られず, 株元よりうね間 方向に離れるにしたがって, 深層まで細根が 分布するようになった。株間の断面の場合に 
株元から $25 \mathrm{~cm}$ の断面

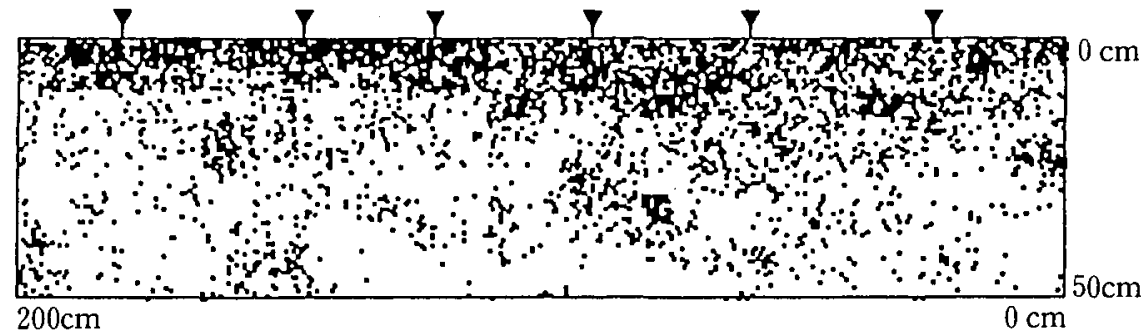

株元から $40 \mathrm{~cm}$ の断面

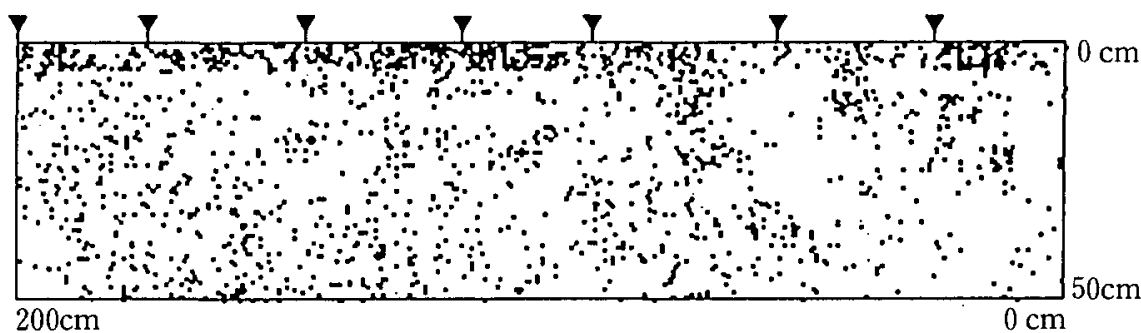

株元から $60 \mathrm{~cm}$ の断面

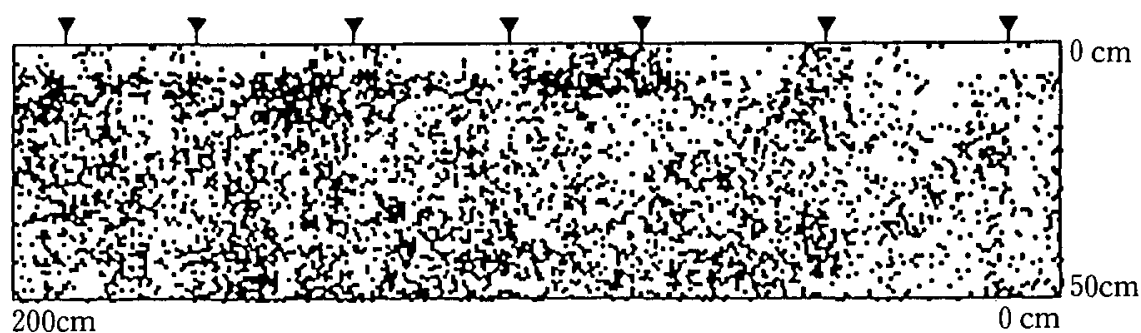

図 1 うねに平行な断面の細根の分布。(正は株位置を示す。）
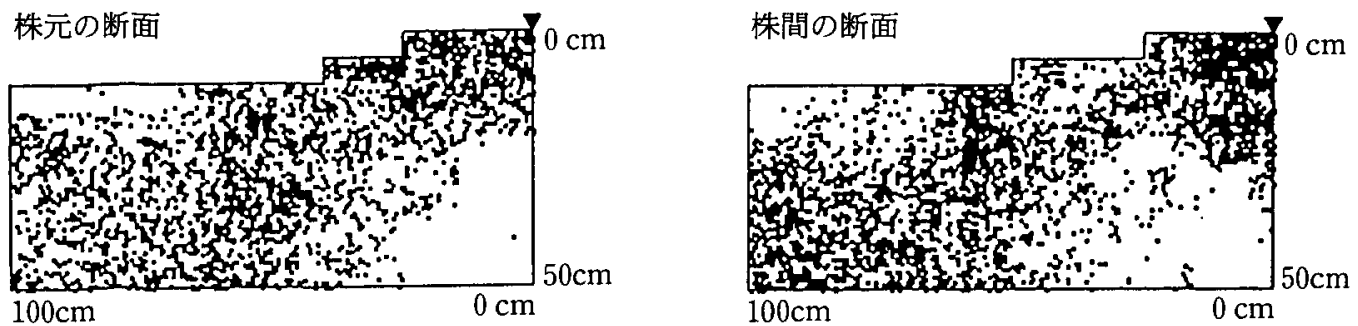

図 2 うねに直角な方向の断面における細根の分布。( 
もほほ同様であったが，株位置直下でもやや 深層まで細根牥分布していた。これらより細 根は株元から放射状に斜め下方向に分布を広 げている様子がうかがわれた。

うねに直角方向の断面（図 2）加，株元 よりうね間方向に $50 \mathrm{~cm}$ 程度離れたところ から，細根が急に増えており，また，この位 置に深耕の跡がみられたことから，断根によ り新しく細根が発生したものと思われる。こ れはうねに平行の断面（図1）において，株 元より $45 \mathrm{~cm}$ の断面よりも $60 \mathrm{~cm}$ の断面の 方が細根が多いという細根の分布状況と一致 している。これらのことから，深耕がうね間 に扔ける細根の量を増やし，深層まで広く分 布させるのに有効であると思われる。なお， 本茶園は前年度夏以降は深耕を行っていな w。

うねに平行の断面（図 1) においては，株 位置と細根の分布との間には明瞭な関係は認 められず，株元より $25 \mathrm{~cm}$ 離れると細根分布 は株相互に重なり合うまでに拡がっているこ とをうかがわせた。

以上の結果から，改良トレンチ法により比 較的少ない労力で埇場断面における細根分布 の様相を把握できることが明かとなった。本 調查法は各種の根系制御技術の効果を確認 し，その改善を図るうえで役立つものと思わ れる。

\section{4 摘 要}

甬場における細根の分布調査を，従来の卜 レンチ法に改良を加えて行った。茶園にトレ ンチを掘り, 調查土垬断面の表面数 $\mathrm{cm}$ の土 を水で洗い流した後, 土壤断面に縦横 $5 \mathrm{~cm}$ 間隔で系を張り，各ます目毎に露出している 細根の数のみ計数した。計数した細根数は視
覚的に分かりやすいように, 細根 1 本を $1 つ$ の点に置き換えて図化表現した。

この改良トレンチ法により, 細根が株元か ら放射状に斜め下方向に分布を拡げているこ とが解るなど, 比較的少ない労力で畨場断面 における細根分布の稼相を把握できることが 明かとなった。

\section{5 謝 辞}

本試験にあたり指導，協力をしていただい た野菜茶試作業技術研究室 (現久留米支場) の佐波哲次研究員, 野菜茶試栽培生理研究室 の松尾喜義主任研究官, および野菜茶試農業 技術研修生の田中義基氏に感謝の意を表しま す。

\section{6 引 用 文 献}

1 ）青野英也・簿瀬好充・田中静夫（1980）: チャの根群の発達とその土地保全機能. 茶試研報, 16, 191-317.

2 ) 㴊之上弘子 (1976): 茶樹の細根分布の深 さに及济す諸条件の影響. 茶業技術, 20， 26-31.

3 ) 志村 喬 (1939)：茶樹の根に関する研究 (予報)。日作紀，11，50-72.

4 ）間曾龍一 (1975)：傾斜地茶園の根系分布 の実態とその環境. 宮崎総農試報， 9, 51-57.

5 ）吉江修司・加賀井茂（1941）: 茶樹の根群 について．茶業組合創立五十周年記念論 文集，第四章第二編，1-29.

6) 前田嘉久美(1981)：トレンチャ利用によ る茶園の深耕. 宮崎総農試報, 15, 33-61.

7 ) 山下正隆 (1989)：茶樹における根群の形 成と断根後の根の再生に関する研究. 野 菜茶試研報, D 2, 29-117. 